\title{
Energy Analysis and Proposals for Sustainability from the Energy Transition
}

\author{
Eduardo Oliveira Teles ${ }^{1 *}$, Marcelo Santana Silva ${ }^{1}$, Francisco Gaudêncio M. Freires ${ }^{2}$, \\ Ednildo Andrade Torres ${ }^{2}$ \\ ${ }^{1}$ Federal Institute of Bahia (IFBA), Brazil and Federal University of Bahia (UFBA), Salvador, Brazil \\ ${ }^{2}$ School of Industrial Engineering (PEI), Federal University of Bahia (UFBA), Salvador, Brazil \\ Email: ${ }^{*}$ eoteles@yahoo.com.br
}

Received 17 March 2015; accepted 12 May 2015; published 15 May 2015

Copyright (C) 2015 by authors and Scientific Research Publishing Inc.

This work is licensed under the Creative Commons Attribution International License (CC BY).

http://creativecommons.org/licenses/by/4.0/

(c) (i) Open Access

\section{Abstract}

The energy transition has become an increasingly attractive and necessary issue nowadays because of the tendency of scarcity and increased demand for fossil energy, and associated environmental impacts-for example, increased emission of greenhouse gases (GHGs), particularly $\mathrm{CO}_{2}$, $\mathrm{CH}_{4}$ and $\mathrm{N}_{2} \mathrm{O}$. From the study of several papers and reports from various international agencies like the World Energy Council (WEC), the International Energy Agency (IEA), the Policy Network for Renewable Energy (REN) and the World Organization of the United Nations (UN), this paper analyzes the global energy context, making a survey of what is being discussed under the theme "energy transition", and suggests ways to reduce the consumption of fossil fuels, aiming at sustainability.

\section{Keywords}

Energy, Sustainable, Energy Transition

\section{Introduction}

Worldwide, efficient, cheap and reliable energy resources are now increasingly being demanded. Certainly, this is the reason why oil and natural gas have dominated the energy market many years and will continue for some time, despite the change in oil price. Furthermore, most of current infrastructure depends on these fuels, meaning that they will be increasingly be disputed by various countries. However, the current debate is about the physical and economical oscillations of these resources, together with a strong political instability in regions

"Corresponding author. 
with oil reserves, without considering awareness of the use of fossil fuels as contribution to global climate change.

There are several worries in the areas of Energy and Environment. Firstly, global warming, caused by emission of greenhouse gases (GHGs) as a result of the burning of fossil fuels. These forecasts about climate changes affect, especially, agriculture and many species of animals and plants. Secondly, the population growth in many countries of the world, particularly in China and India. Thirdly, the continued growth trend of supply and demand of energy in the world. Fourthly, the global dependence on oil and its derivatives, in particular from the countries of the Middle East.

The strong price instability promotes the increase of Biofuels use. In July 2008, the price of oil was $\$ 147$ per barrel and within a period of six months showed a decline, reaching \$30. In 2012, the average price of Brent crude oil was US $\$ 111.65$ per barrel [1]. The picture of the period between 2008 and 2012 clearly shows the consecutive increases in the price, and soon, the decrease of price.

The energy transitions get more attention due to increasing concerns about the future availability of energy sourced from fossil fuels and the impact of their use on the environment [2]. The increase in oil and gas reserves is conditioned to the exploration in increasingly difficult environments (unconventional sources and pre-salt). However, these projects become unviable due to reduction of oil prices; the exploitation of these resources is more expensive, has higher emissions of greenhouse gases, and is more risky for the environment compared with conventional sources [3]-[5]. Therefore, there are increasing requests for fossil fuels to be replaced by alternative sources of energy cleaner and renewable. However, the production costs of the clean and renewable energy are still high and the profitability of this market is quite low.

The purpose of this article is to show the reality of the areas of Energy and Environment, through the analysis of the energy matrix in the world and checking the energy transition possibilities. Besides, this article mentions the participation of some emerging countries and shows the importance of increasing the studies on renewable energy.

\section{Methodology}

This research was divided into stages, namely, collection, description, tabulation and analysis of a wide range of current data on energy topics, sustainability and energy transition.

The analysis of the global energy sector (the current consumption and prospects for use of several energy sources) was held from reports of the World Energy Council (WEC), the International Energy Agency (IEA), the Renewable Energy Policy Network (REN), the Intergovernmental Panel on Climate Change (IPCC) of the United Nations (UN) and other international institutions such as the Institute the Pew Charitable Truts.

The analysis of these reports has details about the energy scene in the world, perspectives and evaluation of the current status in energy consumption. At the same time, there was a survey of information about the theme of "energy transition". In this survey, the collected material was classified into three research areas: 1) history of transition energy, 2) management of the energy transition, and 3) the transition in the oil and gas energy systems.

Based on information from the reports, projections of the energy matrix and study of several works on energy transition, is displayed the main study trends and best sustainable development paths. Finally, there is the analysis of the influence that the energy transition has on sustainability and the usage of energy sources, showing paths for this conversion.

\section{Contextualization of Energy}

The energy sector is strategic for the economy of nations and very important to social development [6] [7]. Approximately three years after the fossil fuel prices have suffered high increases due to the economic crisis of 2008 and 2009, the world faced a recession that did not happened for a long time. This recession has generated serious risks to political and economic stability, represented largely by the world's dependence on fossil fuels. Events like this one show the need to a change of the energy matrix in the world, converging to clean energy. The energy transition with a focus on sustainability would increase the energy security of the world, would promote economic growth to a long period and would face environmental challenges such as anthropogenic climate change. Therefore, this revolution will demand unprecedented investment in Research and Development (R \& D) of clean technologies and low-carbon, in the next decades. 
Despite the significant increase in global investment in renewable energy, led by the wind, solar and biomass, the growth of fossil fuels has increased in significant volumes too. This is not surprising, considering the fact that more than a quarter of the world's population, which is approximately 1.6 billion people still not having access to electricity, according to the report by the World Energy Council [8]. The largest growth in energy consumption comes from Asia, particularly China and India. These two countries, according to projections by the IEA, will represent more than $50 \%$ of total growth in global energy demand by 2030 [9]. By another hand, after the natural disaster happened in Japan, the uncertainty regarding some energy sources, for example the nuclear energy, increased significantly.

In accordance with data from the International Energy Agency [10], the consumption of primary energy in the world is increasing every year and the scenario is of growing in all sources. According to the same report, fossil fuels continue to be the main sources of energy in the world, but the share of oil will fall from $32 \%$ to $27 \%$ in 2035. Moreover, it is estimated incremental increases in the price of oil that will come in order to $\$ 125 / \mathrm{barrel}$ in 2035. This increase in demand is mainly supported by incentives to overcome market barriers, the decline in technology costs, increase in prices of fossil fuels, consumption mode of modern society and the increased purchasing power.

The International Energy Agency expects that between 2008 and 2030, due to the projected growth in 1.0\% of the total world average, China and India will even get greater oil consumption averages [11]. Because of this short scenario, in case of any disruption of supply influenced by the monopoly power of the Oil Producers Exporting Countries Organization-OPEC, or even a terrorist attacks in countries with enormous quantities of reserves, the oil-importing countries would be significantly political and socio-economically vulnerable. In accordance with the World Energy Council, in their report called "Roadmap towards a Competitive European Energy Market", currently about $50 \%$ of all European energy is being imported, and this tends to grow to $70 \%$ in 2030 .

The World Energy Council showed the growth of emerging economies, especially China and India, which raised and placed the availability of energy as a priority item on the global agenda. Moreover, it is assumed the occurrence of the doubling of energy demand on earth by 2050. Fossil fuels will continue to be the main component of the energy mix for at least another generation [12].

In 2010, the WEC mapped and developed future scenarios of global energy, in the report entitled "Logistics Bottlenecks", with a focus on fossil and renewable fuels most used in the world [13]. In this report, was made a projection of consumption and demand for 2020 and 2050, using data from the International Energy AgencyIEA and other sources, the Asia/Pacific was the largest producer and consumer of coal worldwide, with more than 3 billion tons, equivalent to $61 \%$ of the market.

Although the environmental unbalance caused from burning coal, it still plays a part of fundamental importance to the energy balance in the world because of their abundance and its well balanced wide geographic scope. According to a projection of the WEC coal production will increase by $20 \%$ in 2020 and $54 \%$ in 2050 compared with 2008 [13]. This way is observed growth in almost all regions of the world, with the exception of European region.

The situation in the oil market is far more complex than the coal, because it is more distant from the consumer markets and its production is limited in some areas, even if two-thirds of reserves are in the Middle East. There are big importers of oil, for example, Europe and Asia/Pacific, which imports about $70 \%$ and $68 \%$, respectively. In the following regions a growth in consumption is expected: Latin America, Africa, Middle East and Asia/Pacific. The other regions showed a reduction in consumption [13].

In 2020, according to the report, the world oil consumption will increase $12 \%$ and the trend is that some regions will reduce its dependence about oil imports, together with the expansion of production rather than reduce the demand and control their consumption [13].

Natural gas also follows a growth path in the both production and their consumption, and is widely used internally, with only $12 \%$ of the export gas produced in 2008 , while oil was on the order of $48 \%$. Latin America will have the highest growth in consumption in the order of $4.2 \%$ annually until 2050 , followed by the regions of Africa (2.8\% per year), Asia/Pacific (2.7\% per year) and the Middle East (2.5\% per year) and North America (0.4\% per year) (WEC, 2010).

\section{The Biofuels Production}

The Study of the Energy Information Administration-EIA with respect to electricity generation in the US, 
shows that the need for energy imports will be offseted by the increase in biofuels, linked to reductions in the demand resulted from the adoption of new fuel economy standards and increasing prices. This fact could provide a downturn in demand for fossil fuels, as the example of the United States (US) [14].

Figure 1 shows the increase of all renewable energy sources, especially biomass and wind power. The big reason for the increase of wind farms and biomass was the regulatory mark that drove a large investment in the sector supported by tributaries and tax credits granted to the respective companies producing these energies.

According to the EIA [14], the global biofuel production hit a record level of more than 34 million toe (tons of oil equivalent) in 2007, representing $1.5 \%$ of the total world fuel consumption. Furthermore, the EIA estimated an annual growth rate of 7\%, which means that by 2030 biofuels will account for about $5 \%$ of total road transport, compared with about $2 \%$ in 2009 [15].

Currently, Brazil and the USA accounts for almost $80 \%$ of global production of biofuels. Both produce bioethanol, the American made from corn, and Brazilian from sugarcane. On the world scene, the USA is now the largest consumer of biofuels, with strong growth in demand in the coming years. Europe, on the other hand, is the largest producer of biodiesel, representing for about $90 \%$ of world production, due to subsidies and other incentives, with an increase in energy imports. China and India are also largest producers of biofuels, particularly bioethanol. Africa and Asia have great potential to become major producers and exporters of biofuels. Southeast Asian countries are big producers of palm oil and could develop a competitive biodiesel for the production and export [14].

In accordance with the American Institute, The Pew Charitable Trusts, in their report entitled "Who is Winning the Clean Energy Race", is shown the clean energy investments made in 2011, according to Table 1.

The United States leads with 48 billion dollars, followed by China with 45.5 billion dollars. Brazil appears in tenth place with $\$ 8$ billion, equivalent to $16.7 \%$ this when compared to the amount of investments in the United States, with a $15 \%$ growth compared to 2010. The document points out that Brazil registered the third largest growth rate in alternative energy production in the last five years between the G20 countries.

In accordance with the same study, at the world level, investment in clean energy, without regard to research and development, has grown 600\% since 2004 and represented a record investment of $\$ 263$ billion, a $6.5 \%$ increase confronted with investments made in 2010 . The production sources that grew most were solar and wind produced by the G20 group [16].

The success for the increasing development of biofuels will depend exclusively on global policies for the production and marketing performed on domestic and international markets, and the strong presence of the Government with the implementation of tax incentives and mainly of subsidies to offset the difference in values compared to other fossil fuels, considering that biofuel production costs are still very high. Another extremely important issue is the establishment of targets at the global level, for the use of biofuels, which could be blended with conventional fuel [17].

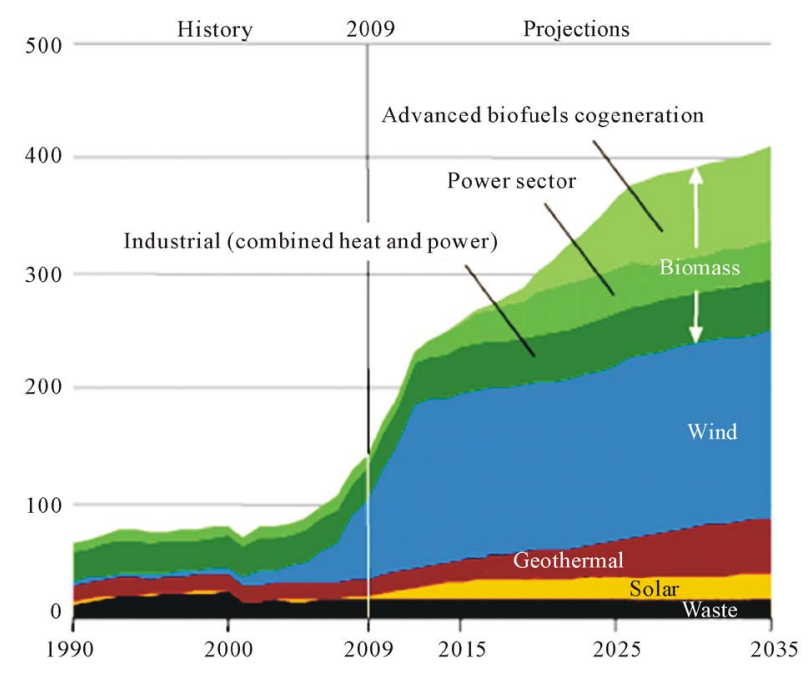

Figure 1. Renewable electricity generation in billion kilowatt per year. Source: EIA (2011). 
Table 1. Countries with greater investment in clean energy in 2011.

\begin{tabular}{cccc}
\hline \multirow{2}{*}{ Ranking } & \multicolumn{3}{c}{ Countries/investment } \\
\cline { 2 - 4 } & Countries & Investment (billions- US \$) & Investments in 2010 (billions- US \$) \\
\hline 1 & USA & 48.0 & 33.7 \\
2 & China & 45.5 & 45.0 \\
3 & Germany & 30.6 & 32.1 \\
4 & Italy & 28.0 & 20.2 \\
5 & The remaining EU - 27 & 11.1 & 15.2 \\
6 & India & 10.2 & 6.6 \\
7 & United Kingdom & 9.4 & 7.0 \\
9 & Japan & 8.6 & 7.0 \\
10 & Spain & 8.6 & 6.9 \\
\hline
\end{tabular}

Currently in the world there are about 10 countries that require oil companies to add a percentage of biofuels to the regular fuel, as example, European Union and Brazil. The Statistical Report produced by BP in 2014 shows, for example, Brazil as world's second largest producer of biofuels, with $24 \%$ of the world total. Ethanol production has risen about $18.5 \%$ and biodiesel, $7.6 \%$. With these values, Brazil begins to bear a mark of $31 \%$ and $10 \%$ of production in the world, respectively.

The IEA has developed a biofuel scenario in road transportation sector, with projection by 2030 , and the participation of all biofuels will be $6.8 \%$, while in 2004 was only $1 \%$. Brazil will control about $30 \%$ biofuels in the transport sector [15].

In this global context, Brazil is classified as a tropical and continental country, holder of a vast expansible land, has a historic opportunity to be qualified as a country with the largest energy reserves from renewable resources of the planet. Therefore, it is necessary to review and improve public policies, as well as its regulatory framework as a whole, so that the industry can emerge in this increasingly attractive market.

\section{Energetic Transition}

The interest about the energy transition has grown considerably in recent years due to increased preoccupation about the impact of the production and use of energy from fossil fuels to the environment.

Transition studies involve the understanding of the interaction between many factors (actors, social, institutional and technological) that influence and feedback resulting in the transformation of the energy system [18] [19]. Smil defines the energy transition as the time that happens between the introduction of a new primary energy source (oil, nuclear power, wind captured by large turbines) and its growth to the point of significant importance (20 - 30 percent) for the global market, or even to become the largest contributor or an absolute leader (over 50 percent) in the supply of national or global energy. The energy transition could also refer to the gradual diffusion of the technology used to produce and distribute energy for domestic, industrial and transport use [20].

The main studies on energy transition were classified in three research areas:

- Energy transition of history;

- Management of the energy transition;

- Transition in oil and gas energy systems.

The big focus of the studies on the transition of energy is the managing the transition to alternative energy or low carbon economy. The transition from traditional to unconventional oil is also happening today in the industry due to the decline of conventional sources [3] [21]. However, few researches have been conducted on this type of transition.

Research suggests a large unconventional oil transition starting before 2030 [4]. The increasing dependence on a few oil producers will continue, because of the fact that the largest reserves are concentrated in the Middle 
East and North Africa. This represents a big problem because most of the countries of these regions are politically and economically unstable. The development of this debate is an indication of wider changes that are happening in the energy sector [22].

Therefore, competition for access to reserves will be even greater, even with the gradual increase of exploitation of unconventional sources. This factor may be one reason why many companies in the sector are involved in the development of alternative energy sources. Investments in this sense will not only help companies to get a competitive edge, but also will provide an opportunity for their green supply chains. It would be a strategic move that could help companies to stay in business and be compatible with a sustainable future.

A change for a renewable energy system will demand large investments and good planning and strategy in the medium and long-term. In addition, there is a socio-political appeal on the development of renewable energies, especially among those who are worried about excessive industrial growth and the domination of basic energy by some groups [23]. It is proposed that, in order to accelerate the transition to renewable energy system, the breaking of all energy systems is necessary. The intervention is necessary to encourage the development of renewable energy sources that are widely available [24]. However, the intense transformation is not an answer to get to a sustainable energy system, at the risk of causing a serious impact on the energy market, economy, environment and society. The solutions to these energy questions require the achievements of feasible actions to a long-term, to ensure that development can be truly sustainable [25] [26].

Therefore, effective policies promote the development of sustainable energy taking into consideration the limits of renewable energy in terms of technical and commercial feasibility. The adoption and abandonment of economic and market policies that provide little incentive for technological innovation and energy development does not help the energy transition in a view of sustainability.

\section{Why Energetic Transition?}

First two important topics can summarizes all the current set for the input of renewable energy: energy security and environmental impact. In 2009, it was estimated that $86.7 \%$ of energy demand in the world was originated from fossil fuels [27]. Present data show that two-thirds of global emissions in 2011 originated from just ten countries, especially China and the US, producing together approximately more than $12 \mathrm{Gt} / \mathrm{CO}_{2}$, which was approximately $40 \%$ of global emissions of dioxide of carbon dioxide $\left(\mathrm{CO}_{2}\right)$, as shown in Figure 2 [28].

This increase in greenhouse gas emissions - GHG took place with more intensity since the Industrial Revolution, the second half of the XVIII century, with a result of the implementation and modernization of the industrial sector, the farming projects and the transport sector.

These gases, among which stands out carbon dioxide $\left(\mathrm{CO}_{2}\right)$ let in the sunlight, but prevent part of the heat in which light is transformed back for space, holding the gas and causing the greenhouse effect. It is important to

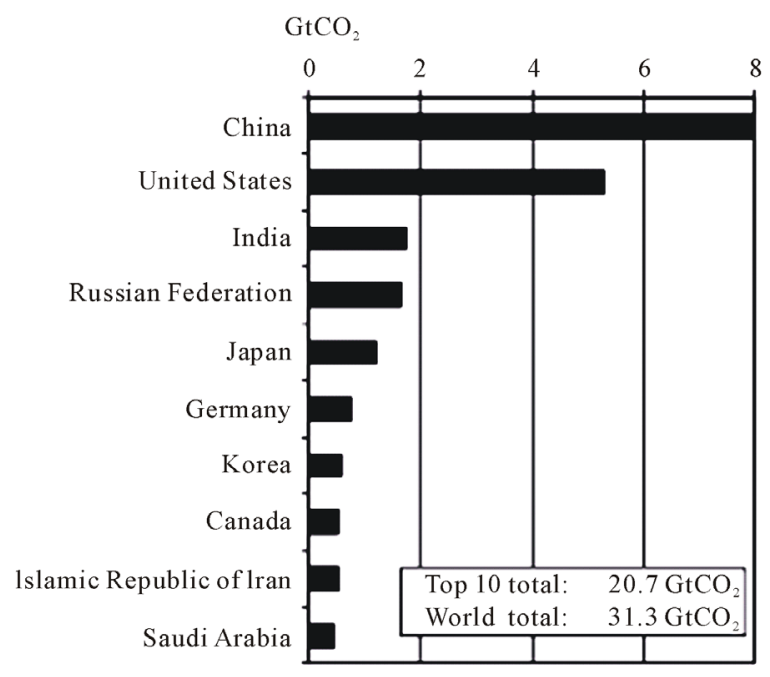

Figure 2. Top 10 emitting countries in 2011. Source: IEA (2013). 
be noted that the greenhouse gases, including water vapor, do not cause harm to health and does not pollute the environment, as well as the greenhouse phenomenon is not a problem. If the effect was not produced, the average temperature of the earth would oscillate around negative $170^{\circ} \mathrm{C}$, making it impossible life on the planet as it is. Human activities that emit greenhouse gases- $\mathrm{GHG}$, especially $\mathrm{CO}_{2}$ and $\mathrm{CH}_{4}$, are related to changes in levels of industrialization and use of land experienced by humanity since 1750 , and a more intense way in the last decades of the last century and early of the XXI century.

In accordance with recent reports by the IPCC, the main sources for the increase in carbon dioxide concentration in the atmosphere are: the use of fossil fuels and the change of management and land use, although the last one, with a small contribution to these increase. The carbon dioxide emission includes all emissions due to the production, distribution and consumption of fossil fuel and also, for example, byproducts of the production of cement, while emissions originating from changes in land handling refer to emissions from deforestation, forest burning, and biomass decomposition resulting from logging [29] [30].

According to the report "Technology Roadmap: Biofuels for Transport" [31], if the pattern of energy consumption continues with the same current levels, the GHG emissions will double by 2050. Furthermore, by 2050 biofuels will account for about $27 \%$ fuel for the transportation sector, and will avoid about $2.1 \mathrm{Gt}$ of $\mathrm{CO}_{2}$ emissions a year when produced sustainably.

In accordance with the AR4, carbon dioxide $\left(\mathrm{CO}_{2}\right)$ annually increased by an average from $6.4 \mathrm{GtC}$ per year in the 1990s to $7.2 \mathrm{GtC}$ per year in 2000-2005. Although the data for the years 2004 and 2005 are approximate estimates, if the emissions associated with changes in land use are considered, must be added $1.6 \mathrm{GtC}$ to these figures per year throughout the $1990 \mathrm{~s}$, although the report point some uncertainties in these estimates. An emission of $1 \mathrm{GtC}(1 \mathrm{GtC}=1$ Giga-ton carbon $=1$ billion tons of carbon $)$ corresponds to $\left.3.67 \mathrm{GtCO}_{2}[29]\right)$.

In AR5 was verified that emissions in a year of $\mathrm{CO}_{2}$ from combustion of fossil fuels and cement production were $8.3 \mathrm{GtC}$ per year (range 7.6 to $9.0 \mathrm{GtC}$ per year), calculated over the period in 2002-2011. In 2011, it was announced $9.5 \mathrm{GtC}$ (range 8.7 to $10.3 \mathrm{GtC}$ per year), representing $54 \%$ above the 1990 level. The liquid $\mathrm{CO}_{2}$ emissions in the year, due to changes in land use that has anthropogenic basis totaled $0.9 \mathrm{GtC}$ per year (range 0.1 to $1.7 \mathrm{GtC}$ per year), the average for the period of 2002-2011 [30].

In total context, between 1750 and 2011, the $\mathrm{CO}_{2}$ emissions from combustion of fossil fuels and cement production sent about $365 \mathrm{GtC}$ ( 335 - $395 \mathrm{GtC}$ interval) into the atmosphere, while deforestation and other changes released $180 \mathrm{GtC}$ (range $100-260 \mathrm{GtC}$ ). These result in accumulated anthropogenic emissions of $545 \mathrm{GtC}$ (range 460 - $630 \mathrm{GtC}$ ) [30].

The concentration of methane gas in the global atmosphere follows the same growth trend. Also according to the IPCC, the concentration increased from a value from the pre-industrial period from about 735 parts per billion - ppb to $1765 \mathrm{ppb}$ in the early $1990 \mathrm{~s}$, and it was in $1774 \mathrm{ppb}$ in 2005 . According to the reflections published in the AR4 and AR5, it is very likely that the observed increase in methane gas concentration is due to anthropogenic activities, mainly as agriculture and the use of fossil fuels [29] [30].

Finally, the concentration of nitrous oxide $\left(\mathrm{N}_{2} \mathrm{O}\right)$ in the global atmosphere. According to the information taken from the publication in question, the concentration of nitrous oxide increased from a value from the pre-industrial period from about $280 \mathrm{ppb}$ to $340 \mathrm{ppb}$ in 2005 . The level of growth has been approximately constant since 1980. Out of this amount, about one third of all the nitric oxide emissions are classified as anthropogenic, primarily due to agriculture [29] [30].

The reports conclude warning that, with continued greenhouse gas emissions at the present rate or an even higher rate, an extra heating would occur and lead to several changes in the global climate system in the course of 21 st century, and very possibly these changes would be much more aggressive than those observed in the 20 th century. In addition, the main consideration of the AR5 is that the climate system warming is unequivocal.

It is important to show that the warming tends to reduce the capture of atmospheric carbon dioxide by the oceans and also the soil, which increases the anthropogenic emission fraction that remain in the atmosphere. In one of the scenarios developed by the IPCC [29], a very heterogeneous world is reported where the key is selfreliance and preservation of local identities, as well as economic development is primarily regionally oriented with more fragmented and slow technological development.

Collaborating with the result of the IPCC report, "Technology Roadmap: Biofuels for Transport" of the IEA also said that if the pattern of energy consumption continue with the same current levels, GHG emissions will double by 2050 . The same report included that by 2050 , biofuels will account for about $27 \%$ of fuel for the transport sector, and will avoid about $2.1 \mathrm{Gt}$ of $\mathrm{CO}_{2}$ emissions per year when produced in a sustainable way, 
worldwide [31].

Thus, it is clear the need for better action in conversion, transmission and distribution of energy. In addition, actions to improve the composition of fossil fuels (decarbonisation), including the diesel fuel, encourage increased renewable energy and bioenergy, enlarge the nuclear energy in a balanced way and invest in cost reduction for capture and storage carbon, are essential for better quality of life and economic stability in the coming years.

\section{Conclusions}

In a general way, the economical and population growth are the most important drivers of increases in $\mathrm{CO}_{2}$ emissions from fossil fuels. The trajectory of population growth between 2000 and 2010 has been practically identical with respect to the past three decades, while economic growth has increased considerably, which leads to considerable increases in energy demand.

A large part of climate change has already become irreversible because of the past emissions. The current methods proposed for reducing the concentration of greenhouse gases are still preliminary, with large margin of doubt about its cost, its application and its probability to succeed.

The analysis of the various reports helps to understand the growth of energy demand and their sources. Enables understand the points of gradual energy transition: the biofuels development, with the projection to coming to $1 / 4$ of the Brazilian matrix in the next decade, for example.

In addition, it became clear that fossil fuels have different representations in environmental instability. For instance, the availability of coal and its geographical dissemination has a very different view of oil. The latter has reserves concentrated in some regions that are politically unstable.

Thus, it is clear that the search for sustainability can be done through energy transition, with the development of effective policy, with good long-term planning, tax incentives and subsidies to reduce the costs of production.

\section{Acknowledgements}

The authors of this paper would like to thank PRPGI/Federal Institute of Education, Science and Technology of Bahia for providing the financial support to complete and publish this article (Edital 07/2014).

\section{References}

[1] Agência Nacional de Petróleo, Gás e Biocumbustíveis-ANP (2012) Boletim Anual de Preços: Preços do petróleo, gás natural e combustíveis nos mercados nacional e internacional. http://www.anp.gov.br/?dw=59757

[2] Fouquet, R. (2010) The Slow Search for Solutions: Lessons from Historical Energy Transitions by Sector and Service. Energy Policy, 38, 6586-6596. http://dx.doi.org/10.1016/j.enpol.2010.06.029

[3] Farrell, A.E. and Brandt, A.R. (2006) Risks of the Oil Transition. Environmental Research Letters, 1, Article ID: 014004. http://dx.doi.org/10.1088/1748-9326/1/1/014004

[4] Greene, D.L., Hopson, J.L. and Li, J. (2006) Have We Run Out of Oil Yet? Oil Peaking Analysis from an Optimist's Perspective. Energy Policy, 34, 515-531. http://dx.doi.org/10.1016/j.enpol.2005.11.025

[5] Mohr, S.H. and Evans, G.M. (2010) Long TERM Prediction of Unconventional Oil Production. Energy Policy, 38, 265-276. http://dx.doi.org/10.1016/j.enpol.2009.09.015

[6] Vera, I. and Langlois, L. (2007) Energy Indicators for Sustainable Development. Energy, 32, 875-882. http://www.sciencedirect.com/science/article/pii/S0360544206002337 http://dx.doi.org/10.1016/j.energy.2006.08.006

[7] Matos, S. and Silvestre, B.S. (2012) Managing Stakeholder Relations When Developing Sustainable Business Models: The Case of the Brazilian Energy Sector. Journal of CleanerProduction, 45, 61-73. http://dx.doi.org/10.1016/j.jclepro.2012.04.023

[8] World Energy Council—WEC (2010) Energy and Urban Innovation. United Kingdom. http://www.worldenergy.org/publications/2010/energy-and-urban-innovation-2010/

[9] World Energy Council—WEC (2010) Roadmap towards a Competitive European Energy Market. United Kingdom. http:/www.worldenergy.org/publications/2010/roadmap-towards-a-competitive-european-energy-market/

[10] Internation Energy Agency_-IEA (2012) World Energy Outlook 2012. OECD/IEA. http://www.worldenergyoutlook.org/publications/weo-2012/

[11] Internation Energy Agency (IEA) (2010) $\mathrm{CO}_{2}$ Emissions from Fuel Combustion Highlights. OECD/IEA. 
http://www.iea.org/media/training/presentations/statisticsmarch/co2highlights.pdf

[12] World Energy Council (WEC) (2008) Criando um Novo Impulso. Declaração do Conselho Mundial de Energia. https://www.yumpu.com/pt/document/view/31640436/criando-um-novo-impulso-world-energy-council

[13] World Energy Council (WEC) (2010) Logistics Bottlenecks. United Kingdom. https://www.worldenergy.org/publications/2010/logistics-bottlenecks-2010/

[14] Internation Energy Agency (IEA) (2011) Technology Roadmap: Biofuels for Transport. OECD/IEA. http://www.iea.org/publications/freepublications/ publication/name,3976,en.html./

[15] Energy Information Administration (EIA) (2015) Annual Energy Outlook 2015 with Projections to 2040. Forrestal Building, Washington, ABR, 2015. http://www.eia.gov/forecasts/aeo/

[16] The Pew Charitable Trusts (2012) Who Is Winning the Clean Energy Race. http://www.pewenvironment.org/news-room/reports/whos-winning-the-clean-energy-race-2011-edition-85899381106

[17] Renewable Energy Policy Network for the 21st Century (REN21) (2012) Renewables 2012 Global Status Report. REN21 Secretariat, Paris. www.ren21.net

[18] Geels, F.W. and Schot, J. (2007) Typology of Sociotechnical Transition Pathways. Research Policy, 36, 399-417. http://dx.doi.org/10.1016/j.respol.2007.01.003

[19] Martens, P. and Rotmans, J. (2005) Transitions in a Globalising World. Futures, 37, 1133-1144. http://dx.doi.org/10.1016/j.futures.2005.02.010

[20] Smil, V. (2008) Moore's Curse and the Great Energy Delusion. American, 2, 34.

[21] Brandt, A.R., Plevin, R.J. and Farrell, A.E. (2010) Dynamics of the Oil Transition: Modeling Capacity, Depletion, and Emissions. Energy, 35, 2852-2860. http://dx.doi.org/10.1016/j.energy.2010.03.014

[22] Wolf, C. (2009) Does Ownership Matter? The Performance and Efficiency of State Oil vs. Private Oil (1987-2006). Energy Policy, 37, 2642-2652. http://dx.doi.org/10.1016/j.enpol.2009.02.041

[23] Lior, N. (2010) Sustainable Energy Development: The Present (2009) Situation and Possible Paths to the Future. Energy, 35, 3976-3994. http://dx.doi.org/10.1016/j.energy.2010.03.034

[24] Verbruggen, A., Fischedick, M., Moomaw, W., Weir, T. and Nadaï, A. (2010) Renewable Energy Costs, Potentials, Barriers: Conceptual Issues. Energy Policy, 38, 850-861. http://dx.doi.org/10.1016/j.enpol.2009.10.036

[25] Omer, A.M. (2008) Energy, Environment and Sustainable Development. Renewable and Sustainable Energy Reviews, 12, 2265-2300. http://dx.doi.org/10.1016/j.rser.2007.05.001

[26] Markevicius, A., Katinas, V., Perednis, E. and Tamasauskiene, M. (2010) Trends and Sustainability Criteria of the Production and Use of Liquid Biofuels. Renewable and Sustainable Energy Reviews, 14, 3226-3231. http://dx.doi.org/10.1016/j.rser.2010.07.015

[27] Brasil. Ministério de Minas e Energia (2012) Boletim mensal dos combustíveis Renováveis, Brasília, SPG, n. 49, fev. 2012.

[28] Internation Energy Agency (IEA) (2013) $\mathrm{CO}_{2}$ Emissions from Fuel Combustion Highlights. OECD/IEA. http:/www.iea.org/publications/freepublications/publication/co2emissionsfromfuelcombustionhighlights2013.pdf

[29] Intergovernmental Panel on Climate Change (IPCC) (2007) Climate Change 2007: The Physical Science BasisSummary for Policymakers. Working Group I. http://www.ipcc.ch/

[30] Intergovernmental Panel on Climate Change (IPCC) (2014) Climate Change 2014: Mitigation of Climate Change. Contribution of Working Group III to the Fifth Assessment Report of the Intergovernmental Panel on Climate Change. In: Edenhofer, O., Pichs-Madruga, R., Sokona, Y., Farahani, E., Kadner, S., Seyboth, K., Adler, A., Baum, I., Brunner, S., Eickemeier, P., Kriemann, B., Savolainen, J., Schlömer, S., von Stechow, C., Zwickel, T. and Minx, J.C., Eds., Cambridge University Press, Cambridge and New York.

[31] Energy Information Administration (EIA) (2011) Annual Energy Outlook 2011 with Projections to 2035. Forrestal Building: Washington, ABR, 2011. http://www.columbia.edu/cu/alliance/documents/EDF/Wednesday/Heal material.pdf 